\title{
Peningkatan Potensi Ekonomi di Kawasan Teluk Tomini melalui Pelatihan Produk Kreasi Limbah Jagung bagi Masyarakat Desa Mebongo Kecamatan Sumalata Kabupaten Gorontalo Utara
}

\author{
Maryam Rahim ${ }^{1}$, Wenny Hulukati ${ }^{2}$ \\ Fakultas IImu Pendidikan, Universitas Negeri Gorontalo Jl. Jend. Sudirman No.6, \\ Dulalowo Tim., Kota Tengah, Kota Gorontalo, Gorontalo 96128, Indonesia \\ email: maryamrahim@ung.ac.id, wennyhulukati@ung.ac.id
}

\begin{abstract}
Abstrak
Masyarakat memiliki peran penting dalam pengembangan potensi ekonomi suatu daerah. Sehubungan dengan hal tersebut dibutuhkan program pemerintah, swasta, dan perguruan tinggi yang dapat mengstimulasi masyarakat. Kegiatan Kuliah Kerja Nyata Tematik ini bertujuan untuk: (1) meningkatkan kreativitas dan produktivitas anggota masyarakat agar mampu memenuhi perekonomian keluarga/masyarakat, (2) meningkatkan keterampilan masyarakat dalam mengolah limbah jagung menjadi produk bernilai ekonomi yang berfungsi sebagai salah satu sumber penghidupan keluarga, (3) melatih mahasiswa dalam menemukan solusi masalah perekonomian masyarakat. Target yang hendak dicapai melalui kegiatan ini adalah: (1) terlaksananya kegiatan pelatihan produk kreasi limbah jagung, (2) meningkatnya keterampilan masyarakat dalam mengolah limbah jagung, dan (3) terbentuknya kelompok-kelompok pengrajin/produsen kreasi limbah jagung yang potensial dalam meningkatkan ekonomi masyarakat di daerah pesisir Teluk Tomini. Pelaksanaan kegiatan dilaksanakan melalui tahapan-tahapan: (a) persiapan dan pembekalan, dan (b) pelaksaanaan di lapangan. Kegiatan persiapan meliputi: (1) menyiapkan administrasi mehasiswa, (2) menyiapkan bahan-bahan dan peralatan yang digunakan dalam kegiatan pembekalan, dan (3) menyiapkan bahanbahan dan peralatan yang digunakan dalam kegiatan pelatihan kepada masyarakat. Kegiatan pembekalan meliputi: (1) menyiapkan administrasi untuk kegiatan pembekalan, (2) melaksanakan pelatihan produk kreasi limbah jagung, di mana keterampilan tersebut akan digunakan oleh mahasiswa dalam melatih anggota masyarakat di lokasi KKN, (3) pemberian materi tentang etika kehidupan bermasyarakat; (b) pelaksanaan di lapangan meliputi kegiatan: (1) survey lokasi, (2) menyusun program, (2) sosialisasi kepada masyarakat tentang program KKN yang akan dilaksanakan, (3) pembentukan kelompok pengrajin, (4) pelaksanaan pelatihan terhadap kelompok pengrajin, dan (5) evaluasi ketercapaian tujuan program. Hasil pelaksanaan kegiatan pengabdian kepada masyarakat ini adalah: (1) meningkatnya pemahaman masyarakat desa Mebongo kecamatan Sumalata Kabupaten Gorontalo Utara tentang pemanfaatan limbah jagung menjadi produk kreasi yang bernilai ekonomi, (2) terbentuknya 9 (sembilan) kelompok pengrajin/produsen kreasi limbah jagung, (3) masyarakat telah memiliki keterampilan yang dapat digunakan sebagai salah satu sumber pendapatan ekonomi keluarga.
\end{abstract}

Keywords: pelatihan, limbah jagung

\section{Abstract}

The community has an important role in developing the economic potential of a region. In connection with this, government, private, and university programs that can stimulate the community are needed. This Thematic Real Work Lecture activity aims to: (1) increase the creativity and productivity of community members so that they are able to fulfill the family / community economy, (2) improve community skills in processing corn waste into economic value products that function as a source of family livelihoods, (2) 3) train students in finding solutions to community economic problems. The targets to be achieved through this activity are: (1) implementing training activities for corn waste creation products, (2) improving community skills in processing corn waste, and (3) forming groups of craftsmen / producers of corn waste creations that have the potential to improve the economy communities in the coastal area of Tomini Bay. The implementation of activities is carried out in stages: (a) preparation and provisioning, and (b) field implementation. Preparatory activities include: (1) preparing student administration, (2) preparing materials and equipment used in debriefing activities, and (3) preparing 
materials and equipment used in training activities for the community. The debriefing activities include: (1) preparing administration for debriefing activities, (2) conducting training on corn waste creation products, in which these skills will be used by students in training community members at KKN locations, (3) providing material on the ethics of social life; (b) implementation in the field includes the following activities: (1) location surveys, (2) compiling programs, (2) socializing to the community about the KKN program to be implemented, (3) forming groups of craftsmen, (4) conducting training for groups of craftsmen, and (5) evaluation of the achievement of program objectives. The results of the implementation of this community service activity are: (1) increasing understanding of the Mebongo village community, Sumalata sub-district, North Gorontalo district about the use of corn waste into economic value creation products, (2) forming 9 (nine) groups of craftsmen / producers of corn waste creations, (3) the community already has skills that can be used as a source of family economic income.

Keywords: training, corn waste

(C) 2019 Maryam Rahim, Wenny Hulukati

Under the license CC BY-SA 4.0

Correspondence author: Irwan Yantu, maryamrahim@ung.ac.id, Gorontalo, Indonesia

\section{PENDAHULUAN}

Teluk Tomini merupakan teluk terbesar di Indonesia, dengan luas lebih dari 6.000.000 hektare (ha) yang berbatasan dengan dengan tiga provinsi, yakni Sulawesi Tengah, Sulawesi Utara, dan Gorontalo. Teluk Tomini memiliki sekitar 90 pulau, yang sebagian berada di provinsi Gorontalo dan Provinsi Sulawesi Tengah (BPS, 2016 dalam Pramuji, 2018). Kawasan Teluk Tomini yang terdiri dari 17 daerah memiliki kawasan pantai yang panjang dan luas, di samping lahan pertanian. Teluk Tomini termasuk salah satu destinasi bahari yang dilirik dunia. Keindahan teluk tomini dibuktikan dengan tersebarnya 1031 hektare kawasan terumbu karang dan 785,10 hektare hutan mangrove (https://tempochannel.com, diakses 19 Januari 2020). Luasnya kawasan ini tentu saja menyimpan berbagai potensi alam yang dapat dikembangkan menjadi produk yang bernilai ekonomi.

Daerah pesisir menyimpan berbagai potensi berupa limbah pertanian yang dapat dikreasikan menjadi produk yang memiliki nilai ekonomi. Salah satu limbah pertanian yang terdapat di desa Mebongo kecamatan Sumalata Kabupaten Gorontalo Utara adalah limbah jagung. Berdasarkan hasil survey, diperoleh data bahwa selama ini masyarakat setempat menggunakan limbah jagung sebagai makanan hewan, itupun 
ketika daun dan tongkolnya belum kering. Limbah jagung yang telah kering biasanya dibakar atau dibiarkan sampai menyatu dengan tanah.

Pada dasarnya limbah jagung tersebut jika diolah akan dapat dijadikan produk yang memiliki nilai jual sehingga bisa menghasilkan pendapatan bagi pengrajinnya. Bentuk-bentuk produk yang merupakan kreasi dari limbah jagung ini dapat berupa rangkaian bunga, hiasan gantungan kunci, kotak tempat pensil, hiasan dinding, bros hiasan jilbab, bingkai foto, dan bentuk kreasi lainnya. Khusus gantungan kunci dan bros, produk ini dapat dijadikan souvenir, baik sebagai ole-ole khas Gorontalo maupun souvenir yang diberikan pada tamu-tamu di pesta pernikahan ataupun pesta ulang tahun. Produk-produk tersebut lebih dapat ditingkatkan secara teknologi tepat guna, sehingga memiliki ciri produk souvenir limbah jagung khas Teluk Tomini.

Program ini dilaksanakan dengan tujuan: (1) meningkatkan kreativitas dan produktivitas anggota masyarakat agar mampu memenuhi perekonomian keluarga/masyarakat, (2) meningkatkan keterampilan masyarakat dalam mengolah limbah jagung menjadi produk bernilai ekonomi yang berfungsi sebagai salah satu sumber penghidupan keluarga, (3) melatih mahasiswa dalam menemukan solusi masalah perekonomian masyarakat. Manfaat yang diperoleh dari program ini adalah: (1) anggota masyarakat pesisir pantai memiliki keterampilan kreatif dalam menghasilkan produk limbah jagung yang dapat menjadi sumber pendapatan ekonomi keluarga, dan (2) mahasiswa memiliki pengalaman aktual dalam membatu mengatasi masalah perekonomian masyarakat.

\section{METODE PELAKSANAAN}

Pelaksanaan kegiatan dilaksanakan melalui tahapan-tahapan:

1. Persiapan dan pembekalan,

a. Persiapan; kegiatan persiapan meliputi: (1) menyiapkan administrasi mahasiswa dan dosen pembimibing lapangan, (2) menyiapkan 
bahan-bahan dan peralatan yang digunakan dalam kegiatan pembekalan, dan (3) menyiapkan bahan-bahan dan peralatan yang digunakan dalam kegiatan pelatihan kepada masyarakat.

b. Pembekalan, kegiatan pembekalan meliputi: (1) menyiapkan administrasi untuk kegiatan pembekalan, (2) pemberian materi kepada mahasiswa tentang produk kreasi limbah jagung, (3) pemberian materi tentang protokol kesehatan untuk mencegah virus covid-19 serta etika kehidupan bermasyarakat agar mahasiswa terhindar dari perilaku yang merugikan masyarakat, diri sendiri, dan lembaga Universitas Negeri Gorontalo;

2. Pelaksaanaan di lapangan.

Pelaksanaan di lapangan meliputi kegiatan:

a) Survey lokasi, yakni melakukan observasi lapangan, identifikasi kepala keluarga, kehidupan sosial-budaya masyarakat, serta ketersediaan limbah jagung. Khusus untuk ketersediaan limbah jagung diperoleh data bahwa limbah tersebut tersedia sebab penduduk di desa tersebut bertani jagung.

b) Sosialisasi program, yakni melakukan sosialisasi kepada masyarakat tentang program KKN Tematik, yang dilaksanakan pada tanggal 11 September 2020.

c) Pembentukan kelompok pengrajin sebanyak 9 kelompok, di mana setiap dusun terdapat 3 kelompok pengrajin, yang dilaksanakan pada tanggal 13 September 2020.

d) Pelaksanaan pelatihan, pelatihan tersebut dilaksanakan dalam bentuk: (1) pelatihan secara umum yang diikuti oleh semua anggota kelompok, dilaksanakan pada tanggal 19 September 2020, dan (2) pelatihan dan pendampingan oleh mahasiswa peserta KKN terhadap kelompok pengrajin selama 2 minggu, dari tanggal 22 - 5 September 2020.

e) Pameran hasil karya kelompok sekaligus sebagai ajang lomba antar kelompok, yang dilaksanakan tanggal 15 Oktober Oktober 2020. 
f) Evaluasi ketercapaian tujuan program. Berdasarkan hasil evaluasi maka dapat disimpulkan bahwa tujuan program KKN Tematik di Desa Mebongo Kecamatan Sumalata Kabupaten Gorontalo Utara tercapai.

\section{HASIL DAN PEMBAHASAN}

Hasil

Pelaksanaan kegiatan pengabdian kepada masysrakat ini telah memberikan hasil, dalam bentuk:

1. Meningkatnya pemahaman masyarakat desa Mebongo kecamatan Sumalata Kabupaten Gorontalo Utara tentang pemanfaatan limbah jagung menjadi produk kreasi yang bernilai ekonomi. Peningkatan pemahaman masyarakat tentang pemanfaatan limbah jagung ini dirasakan penting, mengingat selama ini masyarakat memandang limbah jagung sebagai sampah sehingga perlu dimusnahkan dengan cara membakarnya, di sisi lain jagung merupakan salah satu jenis tanaman hasil pertanian masyarakat desa Mebongo.

2. Meningkatnya kreativitas dan produktivitas anggota masyarakat dalam memenuhi perekonomian keluarga/masyarakat melalui pemanfaatan limbah jagung.

3. Telah terbentuk 9 (sembilan) kelompok pengrajin/produsen kreasi limbah jagung. Kelompok-kelompok ini telah terampil membuat produk kreasi limbah jagung, seperti rangkaian bunga, kap lampu, hiasan gantungan kunci, bros, dan hiasan dinding.

4. Masyarakat telah memiliki keterampilan yang dapat digunakan sebagai salah satu sumber pendapatan ekonomi keluarga. Hasil yang dicapai ini diharapkan akan dapat dimanfaatkan oleh masyarakat khususnya kelompok pengrajin yang telah dilatih sebagai sumber pendapatan keluarga, sehingga dapat membantu keluarga dalam memenuhi kebutuhan sehari-hari. 


\section{Pembahasan}

Pembangunan di bidang ekonomi memiliki peran strategis dalam meningkatkan kesejahteraan masyarakat, terutama dalam pemenuhan kebutuhan hidup sehari-hari dari anggota masyarakat. Data tentang tingginya angka kemiskinan di Indonesia menjadi indikator masih rendahnya kesejahteraan masyarakat Indonesia. Oleh sebab itu perlu dilakukan berbagai upaya yang berkelanjutan dalam membantu mewujudkan masyarakat yang sejahtera.

Upaya membantu mewujudkan kesejahteraan masyarakat tentu saja tidak lepas dari peran serta anggota masyarakat itu sendiri. Masyarakat harus memiliki motivasi sebagai kekuatan yang mendorongnya untuk menjadi pelaku ekonomi, dalam hal ini menjadi pihak yang mampu menghasilkan sesuatu yang bernilai ekonomi sebagai sumber dalam memenuhi kebutuhan keluarga. Mengolah limbah laut atau limbah pertanian menjadi salah satu cara yang dapat dilakukan oleh anggota untuk menjadi pelaku ekonomi.

Indonesia merupakan salah satu Negara agraris yang memiliki berbagai ragam hasil pertanian mulai dari padi, ubi kayu, jagung dan sejumlah hasil pertanian lainnya yang sangat penting dalam perindustrian nasional (Mahardika dan Dewi, dalam Chairunnisa dan Ciptandi, 2018: 261). Kegiatan pascapanen dan pengolahan hasil pertanian termasuk pemanfaatan produk sampingan dan sisa pengolahan yang masih kurang dilakukan, menyebabkan jumlah limbah pertanian terus menerus meningkat. Berdasarkan data Status Lingkungan Hidup Indonesia (SLHI) tahun 2011, limbah organik mencapai 70\%, sedangkan limbah non organik mencapai 30\% (Chairunnisa dan Ciptandi, 2018: 261-262).

Limbah pertanian seperti jerami padi, sekam, jerami jagung, limbah sayuran, gulma yang ada di lahan, sampai saat ini belum dimanfaatkan sebagai bahan kompos, akan tetapi dibuang ke luar lahan atau di bakar. Hal ini dilakukan petani karena mereka menganggap limbah pertanian adalah sampah yang jika dibiarkan berada di lahan akan menjadi sarang 
hama seperti tikus (Jefrizal, Kusumawati, dan Hayati, 2018). "Produksi limbah pertanian dan agroindustri sampai saat ini masih merupakan produk yang belum dimanfaatkan secara baik, ..." (Agustono, dkk, 2017). Dalam mewujudkan potensi limbah/residu pertanian menjadi kekuatan ekonomi lokal, diperlukan suatu proses yang dapat mengintegrasikan pengolahan limbah/residu tersebut menjadi produk yang memiliki nilai ekonomi (Herry, 2014). Selama ini paradigma manusia tentang sampah/limbah hanyalah dengan membuangnya ketempat sampah ataupun dibakar, dan dibuang ke sungai, yang tentu saja berdampak buruk untuk lingkungan, maka untuk menghindari hal tersebut paradigma itu harus dirubah dengan prinsip pengolahan sampah berbasis masyarakat, yaitu: mengurangi (reduce), menggunakan kembali (reuse), mendaur ulang (recycle) (Fatoni, Rinaldy, dan Darmawan, 2017).

Jagung menghasilkan limbah berupa kulit, dan tongkol yang dapat diolah menjadi produk kreatif yang memiliki nilai ekonomi. Kulit jagung dapat diolah dan dikreasikan menjadi bunga, dan bros; tongkol jagung dapat diolah dan dikreasikan menjadi hiasan gantungan kunci, menjadi bros, hiasan pensil, kap lampu, dan lainnya. Jika dicermati produk kreasi limbah jagung tersebut memiliki nilai jual yang tinggi sebab sangat bersentuhan dengan kebutuhan masyarakat di saat ini dan yang akan datang, sehingga dapat dijadikan sebagai salah satu sumber penghasilan anggota masyarakat secara berkelanjutan, khususnya masyarakat yang tinggal di pesisir pantai Teluk Tomini. Di era persaingan hidup yang semakin tinggi ini diharapkan anggota masyarakat khususnya kepala keluarga memiliki sumber penghasilan untuk memenuhi kebutuhan hidupnya dan keluarganya, sehingga akan lahir generasi muda pesisir pantai Teluk Tomini yang memiliki keunggulan dalam persaingan hidup yang semakin ketat dan dinamis.

Kehidupan keluarga dan masyarakat pada umumnya turut dipengaruhi oleh faktor ekonomi. Faktor ini menjadi penting sebab sangat berkaitan dengan berbagai aspek dalam kehidupan keluarga dan masyarakat itu sendiri, seperti aspek pendidikan, dan kesehatan. Kaitan 
ekonomi dengan kesehatan keluarga dijelaskan oleh Budi (2017) bahwa kondisi ekonomi sangat berpengaruh terhadap sanitasi lingkungan dan kesehatan keluarga.

Banyak persoalan yang terjadi dalam keluarga dan masyarakat yang disebabkan oleh faktor ekonomi. Kondisi ini sangat nyata di masa pandemik covid-19 sekarang ini. Kondisi pandemik telah membuat banyak orang yang kehilangan pekerjaan sebagai sumber kehidupan ekonomi keluarga, yang selanjutnya menjadi penyebab terjadinya permasalahan dalam keluarga. Menurut Hadiwardoyo, (2020) pandemik covid-19 telah menimbulkan kerugian ekonomi secara nasional.

Sejak kasus Covid-19 meningkat di Indonesia, berbagai permasalahan sosial dan ekonomi muncul di tengah masyarakat (Tirto, dalam Alifa, 2019). Masalah sosial sendiri merupakan suatu ketidaksesuaian antara unsur-unsur kebudayaan atau masyarakat yang membahayakan kehidupan kelompok sosial atau menghambat terpenuhinya keinginan-keinginan pokok warga kelompok sosial tersebut sehingga menyebabkan kepincangan ikatan sosial (Soekanto, dalam Alifa, 2019). Masalah sosial timbul dari kekurangan-kekurangan dalam diri manusia atau kelompok sosial yang bersumber pada faktor-faktor ekonomis, biologis, biopsikologis, dan kebudayaan. Alifa (2019) menguraikan beberapa permasalahan sosial ekonomi sebagai dampak pandemi covid-19, yakni: (1) kelangkaan barang dan kenaikan harga barang, (2) disorganisasi dan disfungsi sosial, (3) meningkatnya tindakan kriminal, (3) melemahnya sektor swasta, dan (5) angka kemiskinan dan pengangguran meningkat.

Permasalahan ekonomi sebagai akibat pandemi ataupun bencana lainnya tidak akan memberikan pengaruh yang sangat parah terhadap ekonomi keluarga jika keluarga memiliki sumber pendapatan secara mandiri. Sebagaimana dikemukakan oleh Wijianto, dan Ulfa (2016) bahwa faktor pendapatan sangat berpengaruh terhadap ekonomi keluarga. Christoper sebagaimana dikutip oleh Sumardi (dalam Wijianto dan Ulfa, 
2016) mendefinisikan pendapatan adalah uang yang diterima oleh seseorang dalam bentuk gaji, upah sewa, bunga, laba dan lain sebagainya.

Mengingat adanya pengaruh pendapatan terhadap ekonomi keluarga, maka pemerintah perlu mengupayakan setiap keluarga non pegawai negeri ataupun swasta agar memiliki sumber pendapatan yang dilakukan secara mandiri (wirausaha). Upaya tersebut antara lain melalui pemberian keterampilan kepada anggota keluarga dalam hal mengolah limbah lingkungan menjadi produk-produk kreasi yang bernilai ekonomi, yakni produk-produk yang dapat dijual sehingga bisa menghasilkan uang yang dapat digunakan keluarga dan masyarakat dalam memenuhi berbagai aspek kehidupan dalam keluarga.

Tidak dapat diingkari bahwa di lingkungan terdapat berbagai limbah tanaman yang terbuang begitu saja yang pada gilirannya akan mencemari lingkungan itu sendiri. Kondisi ini disebabkan oleh kurangnya pengetahuan dan keterampilan masyarakat dalam mengolah limbah tanaman menjadi berbagai produk kreasi yang bernilai ekonomi. Kegiatan pengabdian masyarakat yang dikemas dalam kegiatan Kuliah Kerja Nyata Tematik yang dilaksanakan di desa Mebongo Kecamatan Sumalata Kabupaten Gorontalo Utara telah berhasil menjadikan masyarakat memiliki keterampilan mengolah limbah jagung menjadi produk-produk kreasi yang bernilai ekonomi. Saat ini, di lokasi tersebut telah terbentuk kelompok-kelompok pengrajin yang memiliki keterampilan mengolah limbah jagung menjadi produk seperti: bunga, kap lampu, hiasan gantungan kunci, dan bros, yang dapat dijual sehingga bisa menjadi salah satu sumber pendapatan keluarga/masyarakat.

\section{KESIMPULAN}

Pelaksanaan kegiatan pengabdian kepada masyarakat dalam bentuk Kuliah Kerja Nyata Tematik oleh mahasiswa ini telah memberikan hasil sebagaimana yang dinyatakan dalam rumusan tujuan kegiatan yang telah ditetapkan sejak awal. Adapun hasil yang telah dicapai adalah: (1) 
meningkatnya keterampilan masyarakat desa Mebongo Kecamatan Sumalata Kabupaten Gorontalo Utara dalam mengolah limbah jagung menjadi produk kreasi yang bernilai ekonomi, seperti rangkaian bunga, hiasan lampu, bros (hiasan jilbab), hiasan gantungan kunci, dan hiasan dinding, (2) terbentuknya 9 (sembilan) kelompok pengrajin/produsen kreasi limbah jagung dengan anggotanya adalah ibu-ibu rumah tangga serta remaja puteri/putera, dan (3) masyarakat telah memiliki keterampilan yang dapat digunakan sebagai salah satu sumber pendapatan ekonomi keluarga.

Peran pemerintah desa dan tokoh-tokoh masyarakat sangat diperlukan untuk keberlangsungan aktivitas kelompok-kelompok pengrajin yang telah terbentuk tersebut. Oleh sebab itu diharapkan peran ini dapat dilaksanakan oleh pemerintah dan tokoh-tokoh masyarakat desa Mebongo Kecamatan Sumalata Kabupaten Gorontalo Utara.

\section{UCAPAN TERIMA KASIH}

Kegiatan pengabdian kepada masyarakat ini tentu saja tidak lepas dari peran perguruan tinggi dalam hal ini Universitas Negeri Gorontalo dan Lembaga Penelitian dan Pengabdian kepada Masyarakat (LPPM) Universitas Negeri Gorontalo, serta dukungan dari pemerintah daerah, kecamatan, dan desa. Oleh sebab itu, tim pelaksana menyampaikan ucapan terima kasih kepada pihak Universitas Negeri Gorontalo sebagai penyedia dana hibah pengabdian kepada masyarakat bagi dosen-dosen; LPPM Universitas Negeri Gorontalo sebagai penyelenggara kegiatan ini mulai dari persiapan, pelaksanaan, hingga monitoring dan evaluasi; serta pemerintah daerah dan kecamatan, khususnya pemerintah kecamatan Sumalata kabupeten Gorontalo Utara dan masyarakat desa Mebongo sebagai lokasi pelaksanaan KKN Tematik, yang telah memfasilitasi dan berpartisipasi dalam kegiatan yang dilaksanakan oleh mahasiswa peserta KKN Tematik. 


\section{REFERENCES}

Alifa, Syadza. Menganalisa Masalah Sosial Ekonomi Masyarakat Terdampak Covid-19. http://puspensos.kemsos.go.id/menganalisamasalah-sosial-ekonomi-masyarakat-terdampak-covid-19

Budi, Erika Rizqyana. 2017. Analisis Kondisi Sosial Ekonomi Masyarakat Ketersediaan Sanitasi. Economic Development Analysis Journal 6 (2) (2017).

Chairunnisa, Magfirah dan Ciptandi, Fajar. 2018. Pengolahan Material Limbah Bonggol Jagung sebagai Produk Aksesoris Fesyen. Jurnal ATRAT V6/N3/09/218.

Fatoni, Nur; Imanuddin, Rinaldy; dan Darmawan. 2017. Pendayagunaan Sampah Menjadi Produk Kerajinan. Jurnal Walisongo DIMASVolume 17, Nomor 1, Mei 2017.

Hadiwardoyo, Wibowo. 2020. Kerugian Ekonomi Nasional Akibat Pandemi Covid-19. Baskara. Journal of Business \& Entrepeneurship, Volume 2 Nomor 2 April 2020. e-ISSN: 2623-0089.

Wijianto, dan Ulfa. 2016. Pengaruh Status Sosial dan Kondisi Ekonomi Keluarga terhadap Motivasi Bekerja bagi Remaja Awal (Usia 12-16 Tahun) di Kabupaten Ponorogo. Al Tijarah Vol. 2, Desember 2016 (190-210). P-ISSN: 2460-4098, e-ISSN: 2528-2948.

https://tempochannel.com, Potensi Wisata di Teluk Tomini. TEMPO Channel

https://lipi.go.id, Kondisi Umum Perairan Teluk Tomini, 1-5 